\title{
Seismic performance of a high-rise residential building model in Purwokerto, Indonesia
}

\author{
Yanuar Haryanto ${ }^{1, *}$, Buntara Sthenly Gan ${ }^{2}$, Nanang Gunawan Wariyatno ${ }^{1}$, and Eva Wahyu Indriyati ${ }^{1}$ \\ ${ }^{1}$ Jenderal Soedirman University, Department of Civil Engineering, Jl. Mayjend. Sungkono KM 5, Blater, Purbalingga, 53371, Indonesia \\ ${ }^{2}$ Nihon University, Department of Architecture, Koriyama 963-8642, Japan
}

\begin{abstract}
We evaluated the performance of a high-rise residential building model in Purwokerto, Indonesia due to the seismic load. The evaluation was performed based on seismic loads given in the 2002 and 2012 Indonesian National Standard (SNI) using linear static analysis, dynamic response analysis and pushover analysis. Based on the linear static analysis, the drift ratio decreased by an average of 34.42 and $32.61 \%$ for the $\mathrm{X}$ and $\mathrm{Y}$ directions respectively. Meanwhile, based on the dynamic response analysis, the drift ratio also decreased by an average of 30.74 and $27.33 \%$ for the $\mathrm{X}$ and $\mathrm{Y}$ directions respectively. In addition, the pushover analysis indicates that the performance of this high-rise residential building model is still at Immediate Occupancy (IO) level. The post-earthquake damage state in which the building remains safe to occupy, essentially retaining the pre-earthquake design strength and stiffness of the structure. The risk of life-threatening injury as a result of structural damage is very low. Although some minor structural repairs may be appropriate, these would generally not be required prior to reoccupancy.
\end{abstract}

\section{Introduction}

These days, the demand for housing has increased because of the economic development and increase in population. One approach to fully use a limited size of land is by vertically developing a high-rise residential building. There are numerous perspectives to consider in constructing a high-rise residential building such as safety, effectiveness and feasibility components. Safety is the major factor to be considered in developing a tall housing. The high-rise residential building is designed in such a way to maintain the vertical gravitational forces and withstand natural disaster such as an earthquake.

Because of its seismicity, Indonesia has made major changes on the earthquake of Indonesian National Standards: SNI 03-1726-2002 [1] to SNI 1726:2012 [2]. These changes will change the building's structural behaviors. Purwokerto has a site-particular estimation of spectral acceleration response for short-period $\left(S_{s}\right)$ is $0.5 \mathrm{~g}$ and one-second $\left(S_{I}\right)$ is $0.2 \mathrm{~g}$. Table 1 demonstrates that a locale with a site-particular estimation of spectral acceleration response for $S_{s}$ larger than or equivalent to $0.5 \mathrm{~g}$ but smaller than $1.0 \mathrm{~g}$ and $S_{I}$ larger than or equivalent to $0.2 \mathrm{~g}$ but smaller than $0.4 \mathrm{~g}$ can be considered as a region with modestly high seismicity potential [3]. In this manner, Purwokerto is a locale with modestly high seismicity potential which needs to follow earthquake-resistant structural framework in every housing structure built up in Purwokerto. The purpose of the current study is to assess the performance of the high-rise residential building model in Purwokerto, Indonesia because of the seismic load. This will create awareness in the society or any parties.

Table 1. Typical seismicity region [3].

\begin{tabular}{|c|c|c|}
\hline Seismicity Region & $\begin{array}{c}\text { Spectral Acceleration } \\
\text { Response, } S_{S} \text { (short-period, } \\
\text { or } 0.2 \text { seconds) }\end{array}$ & $\begin{array}{c}\text { Spectral Acceleration } \\
\text { Response, } S_{1} \text { (long-period, } \\
\text { or } 1.0 \text { second) }\end{array}$ \\
\hline Low & less than $0.250 \mathrm{~g}$ & less than $0.100 \mathrm{~g}$ \\
\hline Moderate & $\begin{array}{l}\text { greater than or equal to } \\
0.250 \mathrm{~g} \text { but less than } 0.500 \mathrm{~g}\end{array}$ & $\begin{array}{l}\text { greater than or equal to } \\
0.100 \mathrm{~g} \text { but less than } 0.200 \mathrm{~g}\end{array}$ \\
\hline Moderately High & $\begin{array}{l}\text { greater than or equal to } \\
0.500 \mathrm{~g} \text { but less than } 1.000 \mathrm{~g}\end{array}$ & $\begin{array}{l}\text { greater than or equal to } \\
0.200 \mathrm{~g} \text { but less than } 0.400 \mathrm{~g}\end{array}$ \\
\hline High & $\begin{array}{l}\text { greater than or equal to } \\
1.000 \mathrm{~g} \text { but less than } 1.500 \mathrm{~g}\end{array}$ & $\begin{array}{l}\text { greater than or equal to } \\
0.400 \mathrm{~g} \text { but less than } 0.600 \mathrm{~g}\end{array}$ \\
\hline Very High & $\begin{array}{l}\text { greater than or equal to } \\
1.500 \mathrm{~g}\end{array}$ & $\begin{array}{l}\text { greater than or equal to } \\
0.600 \mathrm{~g}\end{array}$ \\
\hline
\end{tabular}

The seismic hazard relies on the danger level as well as the susceptibility to know plausible seismic impact [4]. The hazard level cannot diminish since it is an environmental occurrence. Thusly, the seismic hazard can be diminished by bringing down the susceptibility. Earthquake engineering comprises two critical terms: performance-based design and performance-based evaluation. The performance-based design focuses on structural design [5-8] while performance-based evaluation focuses on a constructed structural analysis [9-11].

\footnotetext{
* Corresponding author: yanuar.haryanto@unsoed.ac.id
} 


\section{Methodology}

\subsection{Building model}

The building model was based on the horizontally irregular structures. The dimension of the $\mathrm{X}$ and $\mathrm{Y}$ axes varied. The soil condition was determined in the moderate state. An improvement was done in the design as well. For instance, the stiffness levels of the positive

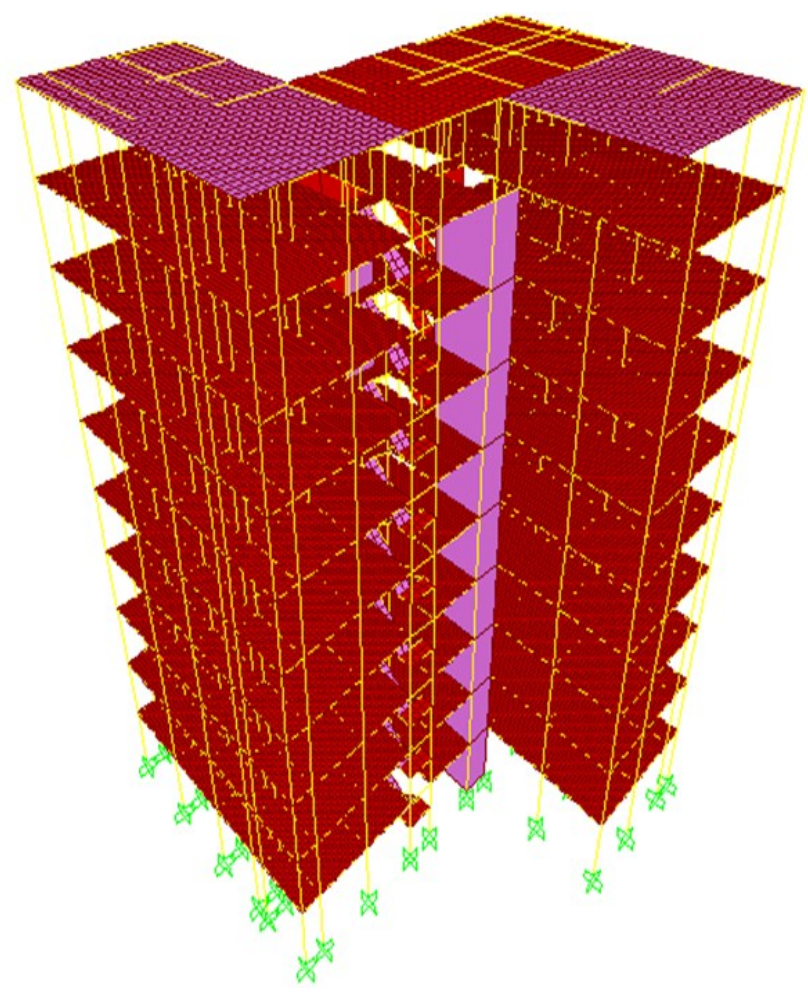

Fig. 1. Three-dimensional (3D) building model.

\subsection{Structure details}

The beams utilized profile I of $600 \times 300 \times 12 \times 17$ with 64 shear connectors. Every pair of shear connectors was attached to a floor with a separation of $18.75 \mathrm{~cm}$ between them on floors 1-9. In the meantime, the columns utilized profile I of $600 \times 300 \times 12 \times 17$ for floors 1-5 and profile I of $250 \times 250 \times 11 \times 11$ for floors $6-10$. The roof utilized profile I of $500 \times 300 \times 11 \times 15$ with 52 shear connectors. Every pair of shear connectors was attached $23.10 \mathrm{~cm}$ separated.

\subsection{Analysis of seismic evaluation}

The static linear analysis was done by using the equivalent static load analysis based on the NonMasonry Model. The base shear $(V)$ happening at the structural basic level was computed based on equations in SNI 1726:2012 and SNI 03-1726-2002. The base shear $(V)$ was then allocated to all the building structures to form the equivalent static seismic load $\left(F_{i}\right)$ through all the joints on every floor.

The spectrum dynamic response seismic loads were utilized in dynamic response analysis by altering the and negative $\mathrm{X}$ and $\mathrm{Y}$ axes were made equivalently. The dead loads were the structures' self-weight, comprised columns, floor plate profile, beams and walls. It was utilized as a distributed load on the beam to involve the load-bearing walls. The plate loads were formed based on the plate dimensional features. The live loads for a housing building type of $250 \mathrm{~kg} / \mathrm{m}^{2}$ were formed as equal loads distributed on the plates. The assessed threedimensional (3D) building model was displayed in Figure 1 and the resulting structure plan was displayed in Figure 2.

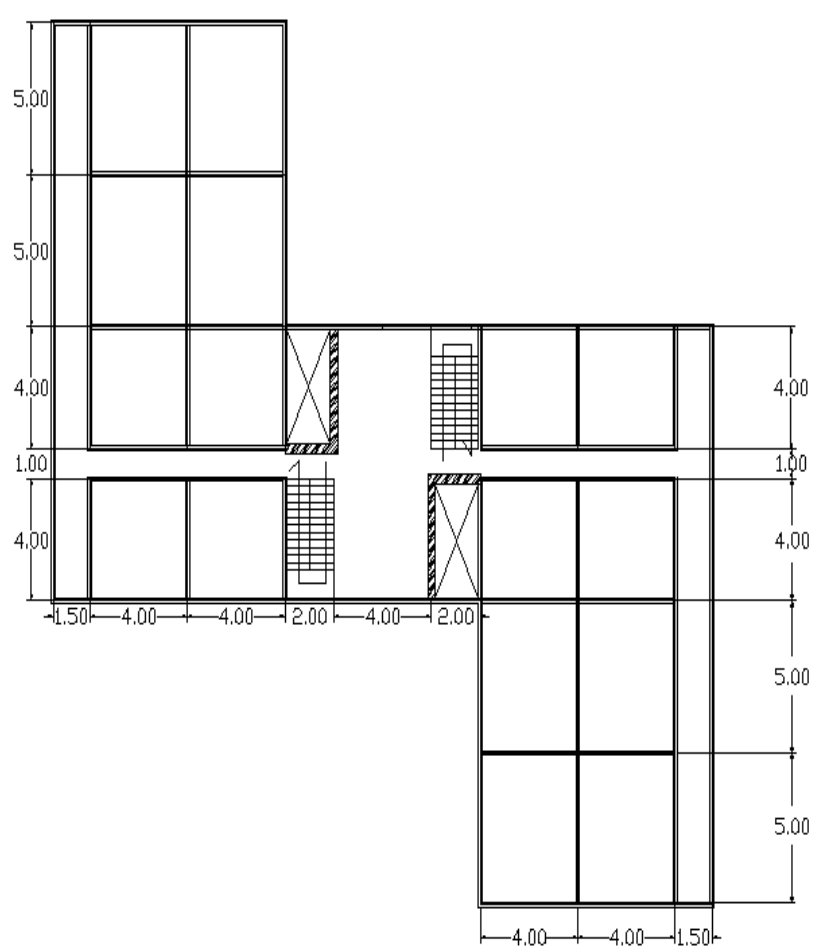

Fig. 2. The structure plan.

location categorization and seismicity level in Purwokerto, Indonesia. The spectrum response was modeled using SAP2000 software while dynamic response analysis utilizes the damping of 0.05 [12]. The function of the response spectrum was defined clearly in Spectrum Response Function Definition. Next, data were inputted into the spectral response accelerations $\left(S_{a}\right)$ and fundamental period of the structure $(T)$. In order to simulate the earthquake arbitrary load towards the building structure model, the effect of the seismic loading on the main directions were set to be $100 \%$ effective. This is because the effect of the seismic loading is in the direction perpendicular to the main direction (30\% effective only).

Pushover analysis $[13,14]$ is a static and nonlinear procedure whereby the value of the structural loading was increased based on the predefined pattern. The relationship between the weak links and failure modes of the structure were found after increasing the magnitude of the loading. The loading is categorized to be monotonic. The effects of the cyclic behavior and load reversals were estimated by using the altered monotonic force-deformation criterion with damping approximations [15].

\footnotetext{
* Corresponding author: yanuar.haryanto@unsoed.ac.id
} 


\section{Result and discussions}

\subsection{Linear static analysis}

The base shear $(V)$ on the moderate soil type occurring in the structure's basic level calculated base on SNI 03$1726-2002$ is $4929.53 \mathrm{kN}$ in the $\mathrm{X}$ direction and 6433.04

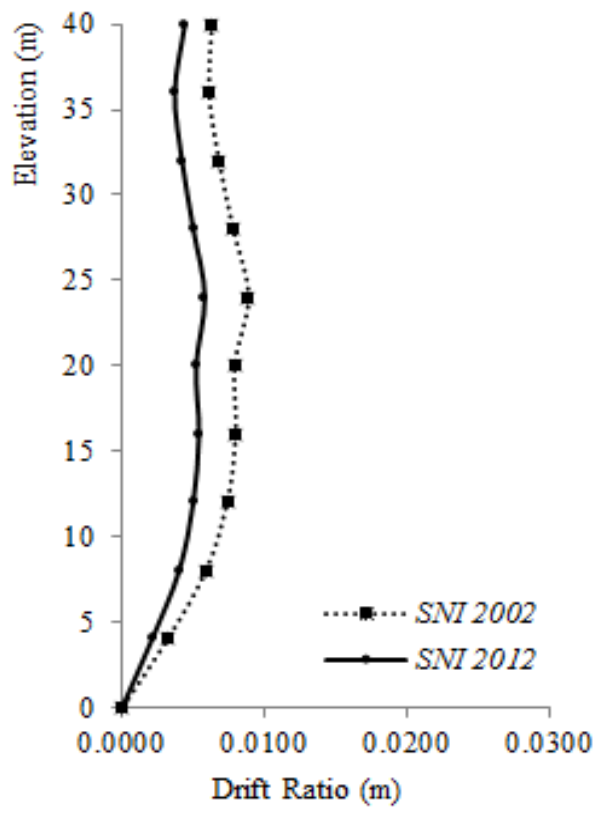

(a) $\mathrm{X}$ direction

Fig. 5. Drift ratio resulting from the linear static analysis

\subsection{Dynamic response analysis}

In general, the response spectrum based on SNI 031726-2002 was larger than SNI 1726:2012. In other words, the high-rise residential building model in

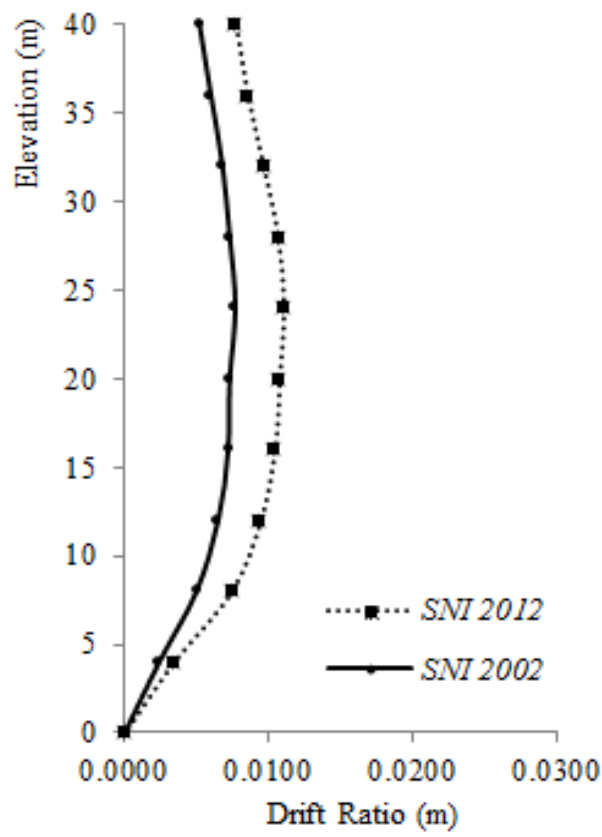

(a) $\mathrm{X}$ direction

Fig. 6. Drift ratio resulting from the dynamic response analysis
$\mathrm{kN}$ in the $\mathrm{Y}$ direction. Meanwhile, the base shear referring to SNI 1726: 2012 is $3426.77 \mathrm{kN}$ in the $\mathrm{X}$ direction and $4471.94 \mathrm{kN}$ in the $\mathrm{Y}$ direction. The base shear is reduced by $30.48 \%$. The drift ratio experiences average decreases of 34.42 and $32.61 \%$ respectively in the $\mathrm{X}$ and $\mathrm{Y}$ directions, as displayed in Figure 5.

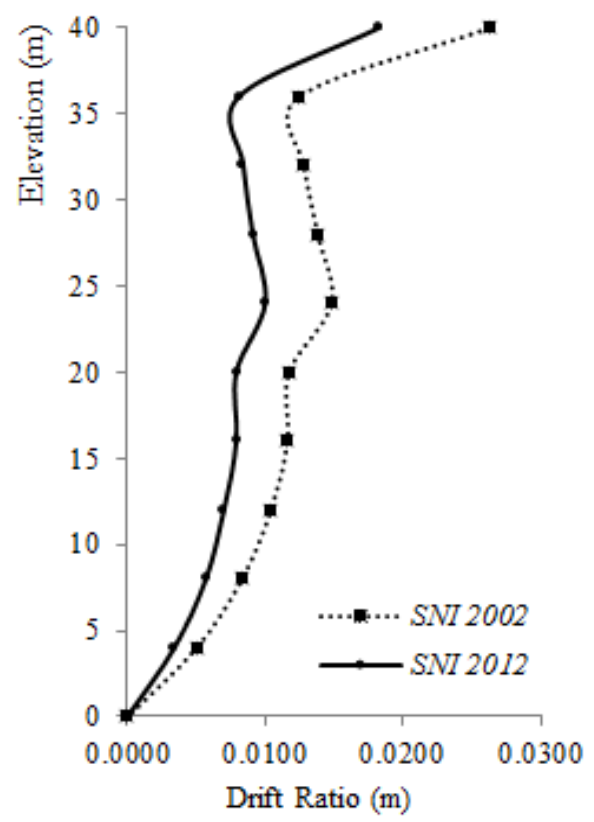

(b) $\mathrm{Y}$ direction

Purwokerto, Indonesia still met the requirements of SNI 1726:2012 even SNI 03-1726-2002 was used. The drift ratio reduced by 30.74 and $27.33 \%$ in the $\mathrm{X}$ and $\mathrm{Y}$ direction respectively as displayed in Figure 6.

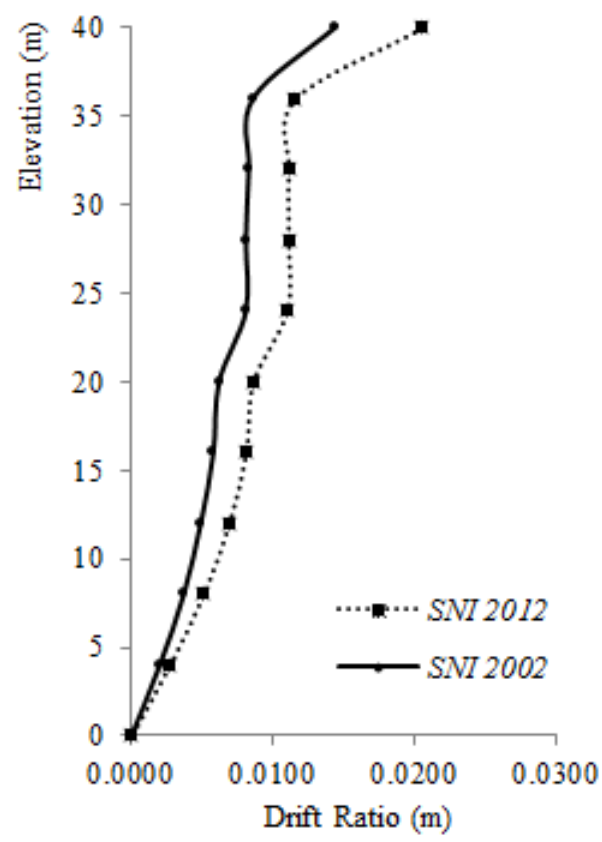

(b) Y direction

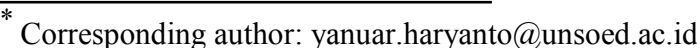




\subsection{Pushover analysis}

The results of the pushover analysis displayed the magnitude of displacement $(D)$ and basic shear $(V)$ when the high-rise residential building model nearly collapsed. As illustrated in Table 2, the base shear reduced by 30.57 and $18.27 \%$ for $\mathrm{X}$ and $\mathrm{Y}$ direction due to the high-rise residential building model in Purwokerto, Indonesia when the performance point was reached. The ductility of the structure was acquired by associating both the yield displacement $\left(\delta_{y}\right)$ and ultimate displacement $\left(\delta_{u}\right)$ as displayed in Table 3.

Table 2. Comparison of pushover analytical results.

\begin{tabular}{ccccc}
\hline \multirow{2}{*}{ Parameter } & \multicolumn{4}{c}{ SNI } \\
\cline { 2 - 5 } & \multicolumn{2}{c}{2002} & \multicolumn{2}{c}{2012} \\
\cline { 2 - 5 } & Dir. X & Dir. Y & Dir. X & Dir. Y \\
\hline$V(\mathrm{~kg})$ & 7571.40 & 7420.61 & 5256.80 & 6064.94 \\
\hline$D(\mathrm{~m})$ & 0.077 & 0.061 & 0.053 & 0.050 \\
\hline
\end{tabular}

Table 3. Ductility of the structure.

\begin{tabular}{cccc}
\hline Direction & $\delta_{y}(\mathrm{~m})$ & $\delta_{u}(\mathrm{~m})$ & Ductility \\
\hline $\mathrm{X}$ & 0.21229 & 0.21714 & 1.02 \\
\hline $\mathrm{Y}$ & 0.19704 & 0.64398 & 3.27 \\
\hline
\end{tabular}

The structural performance of the high-rise residential building model was distinguished by drift ratio. The pushover analysis results displayed that the drift ratio was 0.193 and $0.153 \%$ for $\mathrm{X}$ and $\mathrm{Y}$ direction respectively for the seismic load of SNI 03-1726-2002. On the other hand, the drift ratio was 0.133 and $0.125 \%$ for $\mathrm{X}$ and $\mathrm{Y}$ direction respectively for the seismic load of SNI 1726:2012. The structural performance was displayed in Table 4.

Table 4. Structural performance.

\begin{tabular}{cccccc}
\hline SNI & Dir. & $\begin{array}{c}\mathrm{D}_{\mathrm{t}} \\
(\mathrm{m})\end{array}$ & $\begin{array}{c}\text { Elevation } \\
(\mathrm{m})\end{array}$ & $\begin{array}{c}\text { Drift } \\
\text { Ratio } \\
(\%)\end{array}$ & $\begin{array}{c}\text { Performance } \\
\text { level }\end{array}$ \\
\hline \multirow{2}{*}{2002} & $\mathrm{X}$ & 0.0770 & 40 & 0.193 & $I O$ \\
\cline { 2 - 6 } & $\mathrm{Y}$ & 0.0610 & 40 & 0.153 & $I O$ \\
\hline \multirow{2}{*}{2012} & $\mathrm{X}$ & 0.0530 & 40 & 0.133 & $I O$ \\
\cline { 2 - 6 } & $\mathrm{Y}$ & 0.0500 & 40 & 0.125 & $I O$ \\
\hline
\end{tabular}

The analyzed drift of this high-rise residential building model in the $\mathrm{Y}$ direction was larger than $\mathrm{X}$ direction as $\mathrm{X}$ direction was stiffer than $\mathrm{Y}$ direction. This phenomenon was due to the shear wall position and the stair structure. The performance of the high-rise residential building model in Purwokerto, Indonesia still remained at the level of Immediate Occupancy (IO) as the value of the drift ratio was less than $1 \%$.

\section{Conclusions}

About $30.48 \%$ reduction in the base shear $(V)$ based on the static linear analysis. Besides that, the drift ratio reduced to 34.42 and $32.61 \%$ in the $\mathrm{X}$ and $\mathrm{Y}$ direction, respectively. However, the drift ratio reduced to 30.74 and $27.33 \%$ in the $\mathrm{X}$ and $\mathrm{Y}$ direction respectively if based on the dynamic response analysis. The results of the pushover analysis displayed that the performance of this high-rise residential building model still at Immediate Occupancy (IO) level. In other words, the building still remained safe to occupy as the preearthquake design strength and stiffness of the structure did not alter greatly. The risk of getting injury due to minor structural damage was low and safe to stay.

Acknowledgements The authors express their gratitude and appreciation to the Research and Public Services Institution (LPPM) of Jenderal Soedirman University (Unsoed), Indonesia, for funding this study. The authors also thank Society Coffee House, Purwokerto, with its great music playlist, for providing a cozy place that allowed the writing process of this manuscript such an enjoyable duty.

\section{References}

1. The National Standardization Agency of Indonesia, SNI 03-1726-2002 Tata cara perencanaan ketahanan gempa untuk bangunan gedung (2002)

2. The National Standardization Agency of Indonesia Badan Standarisasi Nasional Indonesia, SNI 1726: 2012 Tata cara perencanaan ketahanan gempa untuk struktur bangunan gedung dan non gedung (2012)

3. Federal Emergency Management Agency, FEMA P154 Rapid visual screening of building for potential seismic hazards: a handbook (2015)

4. Y. Haryanto, G.H. Sudibyo, F.C.A. Effendi, Procedia Eng. 171, 1025 (2017)

5. A.V. Bergami, X. Liu, C. Nuti, J. Civil Eng. Architect. Res. 2, 842 (2015)

6. J. Seo, J.W. Hu, B. Davaajamts, Sustainability 7, 14287 (2015)

7. S. Bhagat, S. Kono, A.C. Wijeyewickrema, K. Kusunoki, S. Tajiri, H. Kashiwa, New technologies for urban safety of mega cities in asia (2015)

8. S.Tesfamariam, K. Goda, Front. Built Environ. 1, 1 (2015)

9. Y. Haryanto, B.S. Gan, N.G. Wariyatno, E.W. Indriyari, ARPN JEAS, 12, 4858 (2017)

10. M. Midorikawa, I. Okawa, M. Iiba, M. Teshigawara, Earthquake Eng. Eng. Seis. 4, 15 (2002)

11. I. Hajirasouliha, K. Pilakoutas, J. Earthquake Eng. 16, 1 (2012)

12. Computer and Structures, Structural and earthquake engineering software SAP2000 (2016)

13. Applied Technology Council. 1996. Seismic evaluation and retrofit of concrete buildings, Vol. 1 (ATC-40)

14. Federal Emergency Management Agency, FEMA 273 NEHRP guidelines for the seismic rehabilitation of buildings (1997)

15. A. Habibullah, S. Pyle, Structure Magazine (1998)

* Corresponding author: yanuar.haryanto $@$,unsoed.ac.id 